\title{
EL CICLO DE IMÁGENES DEL LIBRO DEL ANTICRISTO [ZARAGOZA: PABLO HURUS, 1496]"
}

\author{
María Jesús LACARRA \\ Universidad de Zaragoza \\ jlacarra@unizar.es
}

Desde los primitivos autores cristianos se fue forjando la creencia en la venida del Anticristo, un personaje terrorífico quien, tras reinar durante tres años y medio, propiciaría el fin de los tiempos. La leyenda, enriquecida a lo largo de la Edad Media, se plasmó no solo en textos morales y religiosos sino también en todo tipo de obras literarias y en un rico material iconográfico. Esta preocupación se acentuaba en los periodos de crisis, cuando «los tiempos turbados» favorecían que se alzaran las voces de profetas, herejes $\mathrm{y}$ visionarios anunciando su llegada. A finales del siglo XV se revitaliza esta idea del fin del universo y se suceden los opúsculos de contenido apocalíptico. Es el momento de la aparición de predicciones mesiánicas centradas en la figura de Fernando el Católico, como el Libro del milenio de Juan de Unay, favorecidas en la Corona de Aragón por una larga tradición vinculada al franciscanismo espiritualista ${ }^{1}$. En este contexto histórico hay que situar la publicación de un volumen impreso en la oficina tipográfica de Pablo Hurus

${ }^{*}$ Este trabajo se ha realizado en el marco del Proyecto de Investigación FFI2012-32259, concedido por el Ministerio de Economía y Competitividad. Se inscribe en el grupo investigador 'Clarisel', que cuenta con la participación económica tanto del Departamento de Ciencia, Tecnología y Universidad del Gobierno de Aragón como del Fondo Social Europeo.

${ }^{1}$ La bibliografía sobre la literatura apologética y la leyenda del Anticristo en España se ha incrementado considerablemente en las últimas décadas, gracias, entre otros, a los trabajos de José Guadalajara Medina, Françoise Gilbert o Isabel Toro Pascua, de obligada consulta para una aproximación al tema. Vid. François Gilbert, La figure de l'Antéchrist dans l'Espagne du siécle d'Or, Villeneuve d'Ascq, Presses Universitaires du Septentrion, 2001, José Guadalajara Medina, Las profecías del Anticristo en la Edad Media, Madrid, Gredos, 1996 y El Anticristo en la España medieval, Madrid, Ediciones del Laberinto, 2004, y María Isabel Toro Pascua, «Imagen y función del Anticristo en algunos textos castellanos del siglo XV», en Via spiritus, 6 (1999), pp. 27-63, y «Milenarismo y profecía en el siglo xv: la tradición del libro de Unay en la Península Ibérica», en Península. Revista de estudos ibéricos, 0 (2003), pp. 29-37. 
en 1496, conocido como Libro del Anticristo de Martín Martínez de Ampiés, aunque en realidad reúne varias obras de temática afín, algunas compuestas por este hidalgo aragonés y otras traducidas. En el conjunto se incluyen el Libro del Anticristo, Libro del Juicio Final, una pieza homilética atribuida a san Vicente Ferrer, precedida de una breve Declaración del propio Ampiés, y la Carta del rabi Samuel, que llegó a tener también difusión exenta. La obra plantea innumerables problemas de carácter bibliográfico que dejo para otro momento, ya que mi intención es aproximarme al material gráfico del primer incunable, desatendido hasta el momento por los estudiosos. Para ello me centraré en la editio princeps y en la primera obra del conjunto, es decir en el ciclo de imágenes del Libro del Anticristo, en el que se concentran la mayoría de las xilografías, con el objetivo de tratar de identificar sus posibles modelos y estudiar su correspondencia textual ${ }^{2}$.

\section{El ciclo de imágenes del Libro del Anticristo}

La figura del Anticristo ha suscitado durante siglos numerosos debates y uno de ellos, quizá menor para los teólogos, era el de su apariencia física. En la literatura apócrifa ya se encuentran algunas descripciones fisiognómicas tempranas que se van plasmando más adelante en representaciones pictóricas. El tema, como ha estudiado Bernard McGinn ${ }^{3}$, no es marginal, ya que incide en la naturaleza del personaje y fue debatido durante siglos: ¿es un demonio, o su encarnación, o un ser humano?, ¿tiene rasgos antropomorfos o monstruosos?, ¿es uno o son varios? Existen tempranas descripciones fisiognómicas del Anticristo que se remontan a textos apocalípticos desde el siglo III, que, aunque responden a tradiciones distintas, coinciden en algunos detalles, como su cabeza llameante, la divergente forma de sus ojos, el derecho sanguinolento y el izquierdo azulado y con dos pupilas, las pestañas blancas, los cabellos hirsutos, etc. Son retratos literarios cercanos a la monstruosidad,

\footnotetext{
${ }^{2}$ Para la trayectoria editorial, consúltese el pionero trabajo de Regula Rohland de Langbehn, «El Libro del Antichristo en castellano», en Studia Hispánica Medievalia, II. Actas de las III Jornadas de Literatura Española Medieval, ed. de Rosa E. Penna y María A. Rosarossa, Buenos Aires, Universidad Católica, 1992, pp. 137-145, con interesantes sugerencias y algunos errores. François Gilbert hizo una edición parcial a partir del primer incunable, Martín Martínez de Ampiés. Libro del Anticristo. Declaración ... del sermón de San Vicente (1496), Pamplona, Eunsa, 1999.

${ }^{3}$ Bernard McGinn, «Portraying Antichrist in the Middle Ages», en The Use and Abuse of Eschatology in the Middle Ages, ed. de Werner Verbeke, Daniel Verhelst y Andries Welkenhuysen, Leuven, Leuven UP, 1988, pp. 1-48. El artículo de José Guadalajara Medina, «El retrato del Anticristo en los textos castellanos medievales», en Actas del VIII Congreso de la Asociación Hispánica de Literatura Medieval, ed. de José Manuel Lucía Megías, Alcalá de Henares, Servicio de Publicaciones. Universidad de Alcalá, 1997, t. I, pp. 729-736, se centra en el retrato literario.
} 
en los que prima el contraste de colores, difícil de plasmar en una xilografía. Las representaciones iconográficas son más tardías y no pueden entenderse sin el apoyo textual que supone un tratado latino, De ortu et tempore Antichristi, escrito por el monje Adso (ca. 920-992), abad de Montier-en-Der, considerado como la primera biografía del Anticristo ${ }^{4}$. Esta obrita de forma epistolar respondía a una petición de la reina Gerberga, esposa de Luis IV de Francia, como se deduce de la lectura del prólogo y del epílogo. Alcanzó una gran popularidad y fue objeto de numerosas adaptaciones durante la Edad Media. Se estructura como una vita, desde la concepción del personaje hasta su muerte, siguiendo el modelo de los relatos hagiográficos, género cultivado por Adso en varias ocasiones. A diferencia de los tratados teológicos, aquí el Anticristo cobra una dimensión humana, que hace uso del terror, pero también del engaño por medio de falsos milagros, como cambiar los elementos o hacer resucitar a los muertos. Ese es el marco textual fundamental que posibilitará un relato visual como el desplegado en las magníficas miniaturas del Hortus deliciarum de Herrada (1125/30-ca. 1195), abadesa de Hohenbourg, pero también un programa iconográfico mucho más popular, como el que finalmente llegará a la imprenta hispana ${ }^{5}$.

Como es práctica frecuente en el taller de los hermanos Hurus la obra está ilustrada, en este caso se utilizan 64 grabados, algunos de ellos repetidos, de los cuales 46 representan escenas del ciclo vital del Anticristo, que serán después copiados, con desigual fortuna, por los impresores burgaleses. Estas 46 escenas permiten seguir los principales episodios de la biografía del Anticristo, de acuerdo con la redacción de Adso de Montier. Su origen judío, descendiente de la tribu de Dan, las relaciones incestuosas de sus padres, su concepción y nacimiento, sus falsos milagros, la reconstrucción del templo de Jerusalén, sus prodigios, el envío de apóstoles por todo el mundo, la sumisión y marca de sus seguidores y la tortura de los infieles, su falsa muerte y resurrección, el seudo-Pentecostés, su destrucción por san Miguel y su caída a los infiernos y, por último, el regreso de Elías y Enoc para predicar la doctrina de Cristo.

Perdido un testimonio que figuraba en la Biblioteca de San Isidro de Madrid, del incunable zaragozano solo se conserva actualmente un ejemplar completo en la Biblioteca Pública de Nueva York, imprescindible para el

\footnotetext{
${ }^{4}$ Para una edición crítica del texto y sus reescrituras, véase Adso Dervensis, De ortu et tempore Antichristi: tractatus qui ab eo dependunt, ed. de D. Verhelst, Turnholt, Brepols, 1976.

${ }^{5}$ El estudio de Nathaniel Campbell, «'Lest He Should Come Unforeseen': The Antichrist Cycle in the Hortus Deliciarum», en Gesta, 54:1 (2015), pp. 85-118, incluye también reproducción de las miniaturas.
} 
estudio de sus imágenes, las cuales representan, de acuerdo con el contenido del texto, las siguientes escenas:

1. Portada (=45). El Anticristo arrastrado al infierno por los diablos (f. 1r); $197 \times 123 \mathrm{~mm}$.

2. Jacob en el lecho de muerte profetiza el futuro a su hijo Dan (f. 2v); $82 \times 130$ $\mathrm{mm}$.

3. Los padres del Anticristo (f. 3v); 199x122 mm.

4. La concepción del Anticristo (f. 4v); 82x132 mm.

5. El nacimiento del Anticristo (f. $5 \mathrm{r}$ ); $81 \times 131 \mathrm{~mm}$.

6. La circuncisión del Anticristo (f. 6r); 82x131mm.

7. El Anticristo se divierte con dos mujeres (f. 7r); $80 \times 130 \mathrm{~mm}$.

8. Reconstrucción del templo de Jerusalén (f. 8r); 84x132 mm.

9. Los alquimistas le enseñan al Anticristo sus técnicas (f. 8r); 80x129 mm.

10. El Anticristo resucita a los padres del rey de Libia (f. $21 \mathrm{v}) ; 82 \times 131 \mathrm{~mm}(=31)$.

11. Elías y Enoc regresan y predican (f. 33v); 140x122 mm (=46).

12. Elías predica contra el Anticristo (f. 11r); $81 \times 128 \mathrm{~mm}$.

13. Enoc predica contra el Anticristo (f. 11v); $80 \times 130 \mathrm{~mm}$.

14. El Anticristo quema los libros de la ley (f. 12r); $80 \times 128 \mathrm{~mm}$.

15. El Anticristo predica un nuevo dogma (f. 13r); $80 \times 128 \mathrm{~mm}$.

16. El Anticristo provoca un maremoto (f. 13v); $81 \times 130 \mathrm{~mm}$.

17. El Anticristo hace florecer un árbol seco (f. $14 \mathrm{r}$ ); $83 \times 130 \mathrm{~mm}$.

18. Milagros del Anticristo: un caballero sale de un huevo, un ciervo surge de una piedra y un castillo pende en el aire sujeto por un hilo (f. 14v); 84x130 mm.

19. El Anticristo marca a los judíos (f.15r); $82 \times 131 \mathrm{~mm}$.

20. El Anticristo manda a sus apóstoles por todo el mundo (f. 16r); $83 \times 132 \mathrm{~mm}$.

21. Un apóstol predica ante el rey de Egipto y su pueblo (f. 16v); 82x132 mm.

22. Un segundo apóstol predica ante el rey de Libia y su pueblo (f. 17r); $82 \times 131 \mathrm{~mm}$.

23. Un tercer apóstol predica ante el rey de Etiopía y su pueblo (f. 17v); 83×132 $\mathrm{mm}$.

24. Un cuarto apóstol predica ante la reina de las amazonas (f. 18r); 83×130 $\mathrm{mm}$.

\footnotetext{
${ }^{6} \mathrm{El}$ ejemplar no figura en el catálogo online de la biblioteca, pero su signatura es *KB+ 1496 (Martinez); descrito en ISTC ia00770000 (British Library, Incunabula Short Title Catalogue, 1980-. [En línea]. Enlace: <http://www.bl.uk/catalogues/istc/> [Consulta: 15/12/2015]); GW 2058 (Gesamtkatalog der Wiegendrucke, Stuttgart \& New York, Anton Hiersemann/ H.P. Kraus, 1925-2003, 27 vols. [En línea]. Enlace: $<\mathrm{http}: / / w w w . g e s a m t k a t a l o g d e r w i e g e n d r u c k e . d e />$ [Consulta: 15/12/2015]) y PhiloBiblon BETA texid 1845; manid 2278 (BETA: Bibliografia Española de Textos Antiguos, dirigida por Charles B. Faulhaber, Ángel Gómez Moreno, Antonio Cortijo Ocaña y Óscar Perea Rodríguez, PhiloBiblon. [En línea]. Enlace: $<$ http://bancroft.berkeley.edu/philobiblon/beta_es.html> [Consulta: 15/12/2015]). La única relación de las imágenes se incluye en el libro de Martin Kurz, Handbuch der iberischen Bilddrucke des XV. Jahrhunderts, Leipzig, Verlag Karl W. Hiersemann, 1931, pp. 35-37, a quien sigo con algún cambio.
} 
25. Predicación del Anticristo (f. 18v); 82x130 mm.

26. Gog, Magog y la reina de las amazonas acuden con su séquito ante el Anticristo (f. 19r); 83x132 mm.

27. Los reyes de Egipto, Libia y Etiopía con su séquito ante el Anticristo (f. $19 \mathrm{v}) ; 82 \mathrm{x} 132 \mathrm{~mm}$.

28. El Anticristo reparte oro y plata (f. 20 r); $82 \times 130 \mathrm{~mm}$.

29. El Anticristo logra que una columna responda a sus preguntas (f. 21r); $83 \times 131 \mathrm{~mm}$.

30. Los reyes de Egipto, Etiopía y su séquito marcados con la señal del Anticristo (f. $21 \mathrm{v}) ; 82 \times 131 \mathrm{~mm}$.

31. $=10$.

32. El rey de Libia y su séquito marcados con la señal del Anticristo (f. 22v); $83 \times 130 \mathrm{~mm}$.

33. Gentes de toda condición se presentan ante el Anticristo (f. 23v); 81x129 $\mathrm{mm}$.

34. Los no creyentes apresados (f. 24r); 80x130 mm.

35. Los no creyentes sometidos a torturas (f. 25r); $82 \times 130 \mathrm{~mm}$.

36. Los no creyentes escondidos en cuevas y muertos de hambre (f. 25v); $84 \times 130 \mathrm{~mm}$.

37. El Anticristo entronizado (f. 26v); $82 \times 131 \mathrm{~mm}$.

38. Asesinato de Elías y Enoc (f. 27r); 80x128mm.

39. Ascenso a los cielos de Elías y Enoc (f. 27v); 84x131mm.

40. El Anticristo se finge muerto y sus seguidores lloran (f. 28v); 81x129 mm.

41. Resurrección del Anticristo (f. 29r); 83x130mm.

42. Falso descenso del Espíritu Santo sobre los apóstoles del Anticristo (f. 29v); $84 \times 132 \mathrm{~mm}$.

43. El Anticristo reúne a sus seguidores en el monte de los Olivos (f. 30v); $198 \times 121 \mathrm{~mm}$.

44. El arcángel san Miguel mata al Anticristo (f. 31v); 198x121mm.

45. $=$ portada.

46. $=11$.

\section{Del Antichrist al Libro del Anticristo}

Una característica de las prensas de los hermanos Hurus es la profusión de grabados que llegaban a Zaragoza desde Europa, en gran parte desde Alemania, y este libro no parece, en principio, una excepción si atendemos al corte germánico de gran parte de sus xilografías. Además, la Vida del Anticristo, junto a Los 15 signos que anunciarán el Juicio Universal que le siguen, tuvo en Alemania una amplia difusión a tenor de los testimonios conservados, que contrastan, como siempre, con la pobreza de nuestro panorama. Su estudio 
permitiría trazar un pormenorizado recorrido por los diferentes medios de transmisión de un texto, desde el manuscrito al libro tipográfico, lo que desbordaría los objetivos de este trabajo. Es necesario, sin embargo, asomarnos, muy brevemente, a esa variedad de formas para conocer la prehistoria de la cual derivan parte de las ilustraciones que se incluyen en el primer incunable.

El Antichrist circuló en tres modalidades: a) manuscritos ilustrados (designados como Endchrist), b) ediciones xilográficas, entendiendo por tales las impresas a partir de un solo bloque de madera, y c) textos tipográficos, aunque fueron las segundas las que conformaron el modelo iconográfico. Los libros xilográficos se han considerado precursores de la imprenta de tipos móviles, aunque hoy se concluye que en muchos casos aparecieron en el mismo periodo, a mediados del siglo xv, y de forma independiente. Se trata de una técnica muy utilizada en obras de temática religiosa (como la Biblia pauperum, Ars moriendi, Speculum humanae salvationis, Apocalipsis, etc.), pero también en almanaques, calendarios o textos escolares, que desapareció pronto cuando la imprenta de tipos móviles fue generalizándose. Los primeros libros xilográficos pueden datarse entre 1447-1450, fecha del más antiguo (Exercitium super Pater noster), y 1470, aunque hasta 1490 aún siguen editándose bajo esta modalidad ejemplares del Donato, coexistiendo con los tipográficos. Pese a la dificultad de su estudio por la escasez de ejemplares conservados, pueden también diferenciarse distintas modalidades. Constaban siempre de pocas hojas (30 o 40), que solían imprimirse a una sola cara para soslayar las dificultades técnicas, con o sin ilustraciones, aunque era mucho más frecuente la segunda opción, ya que se utilizaban de forma preferente para difundir un mensaje entre los iletrados a través de las imágenes. Estas podían ir acompañadas de un breve texto entallado en el mismo bloque de madera (xilográfico) o añadido de forma manuscrita («quiro-xilográfico»), aunque las posibilidades combinatorias son múltiples, incluso dentro del mismo libro ${ }^{7}$. Pese a que esta modalidad de imprimir estuvo muy limitada a los países germánicos, tiene su repercusión indirecta en algunos de nuestros incunables, como ocurre con el Ars moriendi $^{8}$ o con el que ahora nos ocupa,

${ }^{7}$ Nigel F. Palmer, «Blockbooks. Texts and illustrations printed from wood blocks», en Journal of the Printing Historical Society, 11 (2008), pp. 5-23; vid. la clasificación de Wilhelm Ludwig Schreiber, Manuel de l'amateur de la gravure sur bois et sur métal au XV siècle. Tome quatrième contenant un catalogue des livres xylographiques et xylo-chirographiques, indiquant les différences de toutes les éditions existantes, Leipzig, Harrassowitz, 1902, con descripción de sus contenidos.

${ }^{8}$ Como ha estudiado Elisa Ruiz, «El Ars moriendi: una preparación para el tránsito», en IX Jornadas Cientificas sobre Documentación: La muerte y sus testimonios escritos, ed. de Juan Carlos Galende Díaz y Javier de Santiago Fernández, Madrid, Área de Conocimiento de Ciencias y Técnicas Historiográficas. Departamento de Ciencias y Técnicas Historiográficas y de Arqueología. Facultad de Geografía e Historia (UCM), 2011, pp. 315-344. 
el Libro del Anticristo. En resumen, si dejamos a un lado los manuscritos, el Antichrist se conserva bajo la forma de libros xilográficos, con texto manuscrito o impreso, datados entre 1449 y 1452, y tipográficos, fechados hacia $1482^{9}$. Bajo la modalidad de tipos móviles, la obra se imprimió tres veces en los primeros años de la década de los 80 por un tipógrafo no identificado de Estrasburgo, dos en alto alemán y otra en bajo alemán, que utilizan las mismas entalladuras ${ }^{10}$.

De las 46 escenas de la Vida del Anticristo, 36 se ilustran con maderas creadas en Estrasburgo, que se corresponden con 34 tacos, pues dos se reutilizan. Son grabados específicos, cortados para ilustrar el Antichrist alemán y seguir visualmente su biografía. La identidad de algunas situaciones hace, sin embargo, que algunas imágenes sean intercambiables; por ejemplo, no es fácil diferenciar a Elías de Enoc predicando $\left(\mathrm{n}^{\mathrm{o}} 12 \mathrm{y} \mathrm{n}^{\mathrm{o}} 13\right)$ ni identificar al rey de Libia del de Egipto ante los que hablan los emisarios del Anticristo $\left(\mathrm{n}^{\mathrm{o}} 21 \mathrm{y} \mathrm{n}^{\mathrm{o}} 22\right)$. Esto produjo ya en los incunables alemanes algún cambio de ubicación que se repite en el texto español; incluso algún grabado como el $\mathrm{n}^{\mathrm{o}}$ 36 corresponde al capítulo quince de Los 15 signos. A su vez, para disimular posibles imperfecciones derivadas de su mal estado, los grabados aparecen ahora rodeados de un marco decorativo con motivos florales, que ya se usaba en el taller dos años antes, como se ve en el incunable De las claras mujeres (Zaragoza: Pablo Hurus, 1494, 24 de octubre).

La obra se distribuye en 45 capítulos, gran parte de ellos acompañados de un grabado insertado tras el epígrafe que ocupa el ancho de página, de forma

\footnotetext{
${ }^{9}$ Según Anneliese Schmitt, «Der Bild text des Antichrist im 15 Jahrhundert. Zum Abhängigkeitsverhältnis der Handschriften, Blockdrucke und Drucke und zu einer möglichen antiburgundischen Tendenz», en E codicibus impressisque. Opstellen over het boek in de Lage Landen voor Elly Cockx-Indestege, 1 (2004), pp. 405-430, las imágenes de los libros xilográficos y del incunable de 1482 dependen del manuscrito Gotha, Herzogl. Bibliothek, Chart. A 225. Los libros xilográficos del Antichrist conservados en Baviera están accesibles en el portal de la Bayerische Landesbibliothek Online. [En línea]. Enlace: $<$ https:// www.bayerische-landesbibliothek-online.de/xylographa-werke\#antichrist $>$ [Consulta: 6/2/2016].

${ }^{10}$ Los items 2050, 2051 y 2052 del Gesamtkatalog der Wiegendrucke, ob. cit., se refieren respectivamente a los dos textos alemanes y al texto en bajo alemán. Para el primero me he servido de una reproducción facsímil, Der Antichrist. Fakssimile der ersten typographischen Ausgabe, realizada a partir del ejemplar de la biblioteca de Frankfurt (Inc. f. 116), con volumen independiente de estudios de Karin Boveland, Christoph Peter Burger y Ruth Steffen, Der Antichrist und die Fünfzehn Zeichen von dem Jüngsten Gericht. Kommentarband, Hamburg, Friedrich Wittig Verlag, 1979. El item GW 2051 está digitalizado en la biblioteca de Munich. [En línea]. Enlace: <http://daten.digitale-sammlungen.de/ bsb00025043/image_1> [Consulta: 7/2/2016]. Todos los grabados alemanes están reproducidos en The illustrated Bartsch. 83. German book illustration before 1500. (Part 4: Anonymous artists 1481 - 1482), ed. de Walter L. Strauss y Carlo Schuler, New York, Abaris Books, 1982, pp. 397-431. Por el contrario, no se incluyen en los volúmenes de Albert Schramm, Der Bilderschmuck der Früdrucke. Die Straßburger Drucker, Leipzig, Hiersemann, 1936-1937, 2 vols.
} 
que cumple así una función estructuradora ${ }^{11}$. En algunos casos el grabado, debido a su formato, ocupa todo el vuelto del folio anterior y sirve de introducción gráfica al capítulo iniciado en el folio siguiente; así ocurre con las imágenes que representan las escenas de «Los padres del Anticristo» $\left(\mathrm{n}^{\circ} 3\right)$, «El Anticristo reúne a sus seguidores en el monte de los Olivos» $\left(n^{\circ} 43\right)$, «El arcángel san Miguel mata al Anticristo» $\left(\mathrm{n}^{\circ} 44\right)$ y «El Anticristo arrastrado al infierno por los diablos» ( $\left.\mathrm{n}^{\mathrm{o}} 45\right)$, que oscilan entre 197x123 mm y 199x122 $\mathrm{mm}$. Ese problema no se plantea del mismo modo en los impresos germánicos, ya que en estos había un claro predominio de la imagen sobre el mensaje escrito, puesto que se dirigían, como sus predecesores, los libros xilográficos, a un público de iletrados. En el Antichrist habitualmente se disponen dos entalladuras por página, con un breve texto que remite en ocasiones a él por medio de un deíctico (Hye) y, cuando se recurre a una entalladura de tamaño mayor, solo se incluye una imagen y un texto. En el Libro del Anticristo varía la relación entre el documento escrito y el gráfico, y este es solo un complemento visual de aquel, como se percibe en estos grabados que muestran el nacimiento del Anticristo por cesárea en el texto español (imagen 1) y en el alemán (imagen 2) ${ }^{12}$.

Otra diferencia importante afecta a la portada del incunable español. La invención de este dispositivo tipográfico está ligada a la aparición del libro impreso, puesto que los manuscritos, a los que inicialmente imitan los primeros incunables, carecían de ella. Del estudio de Mónica Morato se desprende que en la oficina tipográfica de Hurus son muy pocas las portadas ilustradas ${ }^{13}$. Si dejamos a un lado las ocupadas por un escudo, este procedimiento se emplea, por ejemplo, en el Tesoro de la pasión (1494) de Andrés de Li o en el Triunfo de María (1495) del mismo Martín Martínez de Ampiés. El diseño de ambas es similar: un grabado ocupa la casi totalidad de la página y debajo se incluye el título xilografíado en letras góticas. El Antichrist carece de portada. En la hoja primera una inicial rameada marca el comienzo, como se hacía en muchos manuscritos, y en el verso una escena de interior muestra en primer plano a dos figuras sentadas en un banco que representan un anciano con barba (padre del Anticristo) y una joven (madre del Anticristo) con sus manos entrelazadas. Detrás de ellos, un diablo con pechos femeninos asoma

${ }^{11}$ La disposición de texto e imagen en la edición de Gilbert, ed. cit., puede inducir en este sentido a error.

${ }^{12}$ Para esta escena en las distintas tradiciones iconográficas, véase Renate Blumenfeld-Kosinski, «Illustration as Commentary in Late Medieval Images of Antichrist's Birth», en Deutsche Vierteljahrsschrift für Literaturwissenschaft und Geistesgeschichte, 63 (1989), pp. 589-607.

${ }^{13}$ Mónica Morato Jiménez, La portada en el libro impreso español: tipología y evolución (14721558), director Fermín de los Reyes Gómez, Madrid, Universidad Complutense de Madrid, 2014. 


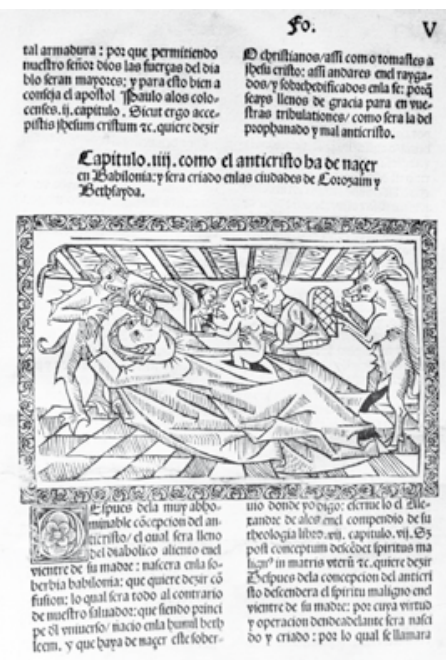

(1) Nacimiento del Anticristo (Zaragoza: Pablo Hurus, 1496), Biblioteca Pública de Nueva York.

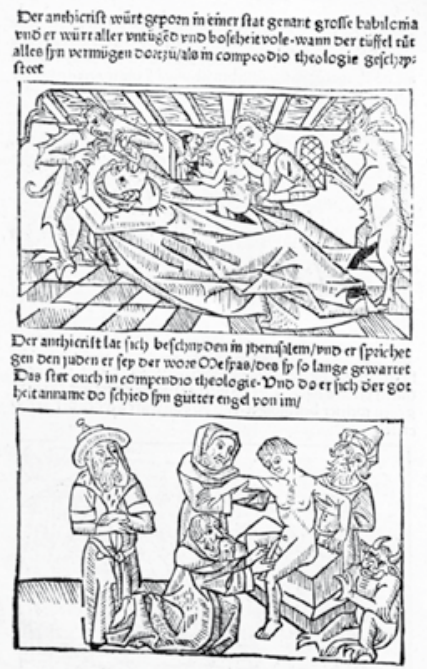

(2) Impreso alemán de donde procede la xilografía anterior. Der Antichrist [Estrasburgo: impresor del Anticristo, ca. 1482]. Munich, Biblioteca estatal de Baviera.

por una ventana y posa sus manos sobre sus cabezas. La imagen, con un eje simétrico presidido por la figura diabólica, sitúa a ambos lados a los padres del Anticristo en un espacio interior con tres ventanas. Se descubre cierta impericia del grabador puesto que el paisaje visible tras el diablo no sigue la misma línea del horizonte que el percibido a través de los otros dos vanos. La escena tiene, sin embargo, una gran fuerza simbólica, puesto que, de acuerdo con el texto, muestra a un padre con su hija y refleja la relación incestuosa de la que nacerá el Anticristo (imagen 3). Su origen como resultado de una unión incestuosa es una adición tardía a su leyenda, que no figuraba en la biografía de Adso de Montier, aunque aparece ya en un poema francés del siglo XIII atribuido a un tal Bérenger. Forma parte de una recreación más popular, de la que se hacen eco los libros alemanes: frente al nacimiento virginal de Jesucristo, el Anticristo se concibe como hijo del peor pecado ${ }^{14}$.

En algunas ocasiones los impresores colocaban una ilustración en el vuelto de la primera hoja, como hizo Hurus con el retrato de Esopo en sus Fábulas (1482) o en el Cordial de las cuatro cosas postrimeras (1491), que terminaba siendo muchas veces la escogida si en posteriores ediciones se buscaba

${ }^{14}$ Andrew Gow, «(En)Gendering Evil: Sinful Conceptions of the Antichrist in the Middle Ages and the Reformation», en Journal of Millennial Studies. Special Issue: Engendering the Millennium, 2:1 (1999). [En línea]. Enlace: <http://www.mille.org/publications/summer99.html> [Consulta: 11/2/2016] y Elizabeth Archibald, Incest and the medieval imagination, Oxford, Clarendon Press, 2001, p. 239, rastrean el motivo. 
una ilustración para la portada. Esto fue lo ocurrido en los impresos burgaleses del Libro del Anticristo. En el taller de Fadrique de Basilea se copió la imagen de los padres, reproducida por Hurus en el f. $3 \mathrm{v}$, que ahora aparecen respecto al modelo zaragozano en posición invertida bajo arco conopial con sus cabezas abarcadas por los brazos del diablo, quien trata así de esforzarse en unirlos (imagen 4$)^{15}$.

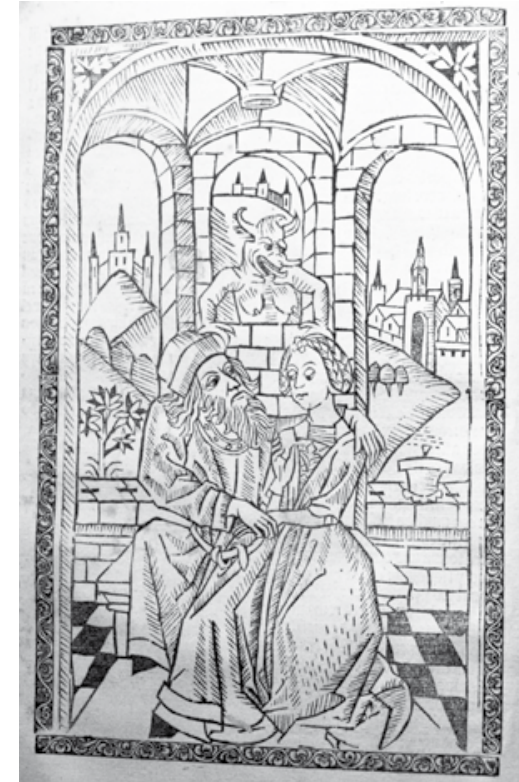

(3) Los padres del Anticristo. La relación incestuosa se expresa por la diferencia de edad y la figura diabólica (Zaragoza: Pablo Hurus, 1496). Biblioteca Pública de Nueva York.

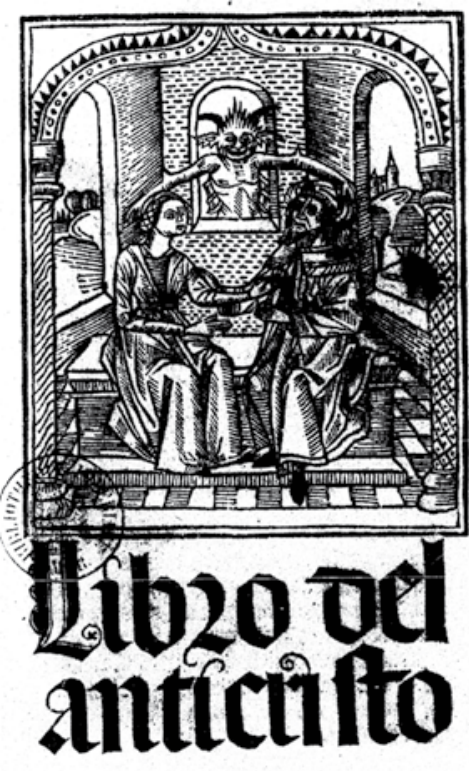

(4) Los padres del Anticristo. Copia. Portada (Burgos: Fadrique de Basilea, 1497). París, Biblioteca Nacional de Francia.

Por el contrario, aunque Pablo Hurus contaba con este mismo taco, no lo eligió para la portada sino el que ilustra la escena de «El Anticristo arrastrado al infierno por los diablos» (imagen 5). Se trata, pues, de una opción premeditada, que le llevó a colocar al frente del libro la caída del Anticristo y no la figura incestuosa de sus padres, buscando así una reafirmación clara de la victoria del bien sobre el mal ${ }^{16}$. También La Vida e historia del rey Apolonio

\footnotetext{
${ }^{15}$ Sirvió de ilustración para la portada de las Actas del III Congreso de la Asociación Hispánica de Literatura Medieval (Salamanca, 3 al 6 de octubre de 1989), Salamanca, Biblioteca Hispánica del siglo xv. Departamento de Literatura Española e Hispanoamericana, 1994.

${ }^{16}$ Esto no evitó que Francisco Méndez, Tipografia española o historia de la introducción, propagación y progresos del arte de la imprenta en España, corregido por D. Hidalgo, Madrid, Imprenta de las Escuelas Pías, 1861, p. 335, opinara que alguno de los grabados «no peca de honesto», una afirmación que podía referirse al que ilustra la escena de «La concepción del Anticristo» (f. 4v).
} 


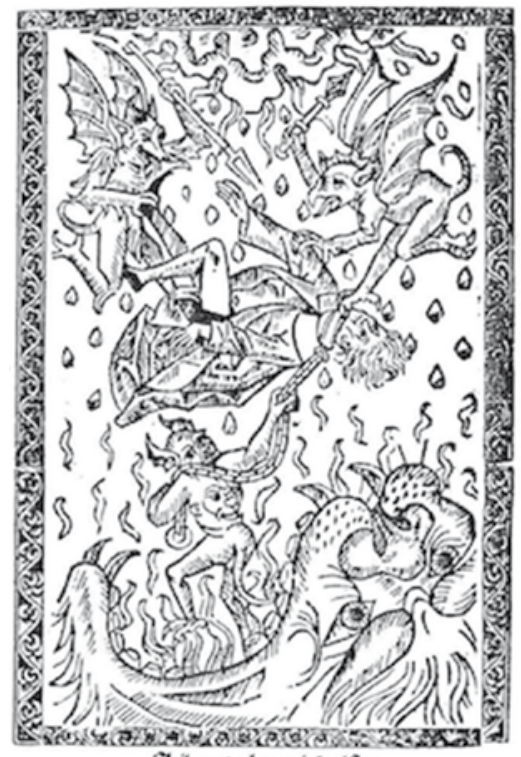

Zibso oel anticbsitto.

(5) El Anticristo arrastrado al infierno por los diablos. Portada.

(Zaragoza: Pablo Hurus, 1496).

Biblioteca Pública de Nueva York.
[Zaragoza: Juan Hurus, ca. 1488] comienza narrando el incesto de Antíoco, pero la primera escena ilustra un episodio ajeno al texto -la muerte de la reina- y no la salida del padre del dormitorio de su hija.

\section{Los «nuevos» grabados}

Hay 9 grabados que no proceden del Antichrist alemán, que corresponden a 8 tacos, puesto que uno de ellos está repetido. Se trata de:

6. La circuncisión del Anticristo (f. 6r); $82 \times 131 \mathrm{~mm}$.

8. Reconstrucción del templo de Jerusalén (f. 8r); 84x132 mm.

10. $=31$. El Anticristo resucita a los padres del rey de Libia (f 9v y f. 21v); 82x131mm.

18. Milagros del Anticristo: un caballero sale de un huevo, un ciervo surge de una piedra $\mathrm{y}$ un castillo pende en el aire sujeto por un hilo (f. 14v); 84x130 mm.

32. El rey de Libia y su séquito marcados con la señal del Anticristo (f. 22v); $83 \times 130 \mathrm{~mm}$.

39. Ascenso a los cielos de Elías y Enoc (f. 27v); 84x131mm.

41. Resurrección del Anticristo (f. 29r); 83x130mm.

42. Falso descenso del Espíritu Santo sobre los apóstoles del Anticristo (f. $29 \mathrm{v}) ; 84 \times 132 \mathrm{~mm}$.

Pese a estar rodeados por el mismo marco claramente se percibe que han sido creados por otro entallador, que traza composiciones más complejas. Las figuras, de rostros graves y vestidas con marcados pliegues, predominan sobre los elementos paisajísticos, preferentemente urbanos o con escasa vegetación. ¿De dónde proceden estos tacos? Para tratar de responder a esta pregunta he seguido un largo proceso, sin resultados aparentes, que me ha llevado, en primer lugar, a repasar los impresos anteriores de idéntica temática, que no son muy abundantes. Baste con indicar que los catálogos en línea de incunables (GW e ISTC) registran siete entradas anteriores a 1496 y alguna más de datación dudosa, pero posiblemente posterior: los tres impresos alemanes del 
Antichrist, ya citados, otros tantos impresos lioneses de una edición bilingüe latín-francés, más un incunable italiano con texto bilingüe latín-italiano ${ }^{17}$. Todos están ilustrados y se distribuyen en dos modelos iconográficos claramente diferentes, el germánico, del que depende la tradición hispana, como hemos visto, y el francés, del que deriva la italiana ${ }^{18}$. La vida del Anticristo también se refiere, con mayor o menor extensión, en otras obras, como el Apocalipsis, las Revelaciones del Pseudo-Metodio, el Speculum humanae salvationis o el Plenarium, con algún grabado alusivo, pero en ninguno de ellos se encuentran los tacos empleados en el impreso de Pablo Hurus.

Algunos de estos nuevos grabados podrían ser considerados referenciales, pues permiten su reubicación en el mismo libro, como ocurre con el número 10 , repetido más adelante $\left(\mathrm{n}^{\mathrm{o}} 31\right)$; la misma imagen sirve para ilustrar dos capítulos diferentes en los que se narra la capacidad portentosa del Anticristo para resucitar a los muertos, pero difícilmente encajarían en otros textos de temática diferente, pues habría que justificar la permanente aparición de una figura diabólica a su espalda. En una primera impresión sorprende el grabado $\mathrm{n}^{\circ} 6$, que ilustra su circuncisión. La edad del personaje, su posición sentado en el trono, la postura de sus manos y su vestimenta resultan inadecuadas para la situación y se oponen al grabado alemán, en el que un jovencito desnudo está rodeado de ancianos. Parece representar más bien el triunfo del Anticristo ante un grupo de judíos, aunque el personaje arrodillado porta un gran cuchillo en su mano derecha. Posiblemente razones morales expliquen la extraña representación. Esta interpretación de la escena quedaría avalada por la copia realizada en Burgos, donde se percibe con claridad cómo el judío lleva en su mano izquierda el cuchillo de pedernal usado en la ceremonia ritual. Así mismo la figura del ángel que escapa por el ángulo derecho de la imagen se corresponde con el texto de Ampiés («Entonce el ángel bueno, que le fue deputado para en guarda como a cada una de las otras criaturas, le dexará», f. 6r). Compárese el grabado inferior del incunable alemán (imagen 7) con la nueva xilografía que incorpora el texto español (imagen 6 y su copia burgalesa, imagen 8 ).

\footnotetext{
${ }^{17}$ Para obtener una perspectiva global, consúltese la entrada ANTICHRISTUS en el GW, donde se reseñan con detalle todas las obras sobre el Anticristo anteriores a 1500. [En línea]. Enlace: $<$ http://www.gesamtkatalogderwiegendrucke.de/docs/ANTICHR.htm\#GW02050> [Consulta: 13/02/2016]. Los incunables franceses descritos también en M. Pellechet, Catalogue général des incunables des bibliothèques de France. Abano-Biblia, Paris, Alphonse Picard et fils, 1897 y Anatole Claudin, Histoire de l'imprimerie en France au XVe et au XVI siècle, Paris, Imprimerie Nationale, vol. 3, 1904, pp. 409-412, y vol. 4, 1914, pp. 188-196.

${ }^{18}$ Para la dependencia entre los incunables italianos (ca. 1490 y 1496) y los lioneses, véase Edoardo Barbieri, «L'Anticristo. Vita, morte e (falsi) miracoli», en L'oggetto libro '98. Arte della stampa, mercato e collezionismo, Milano, Sylvestre Bonnard, 1999, pp. 18-27 y «Un 'unicum' delle 'Auctoritates de Antichristo'. I segreti dell'Anticristo. Venti episodi di venti capitoli e venti silografie», en L'Erasmo. Bimestrale della civiltà europea, 24 (2004), pp. 79-87.
} 


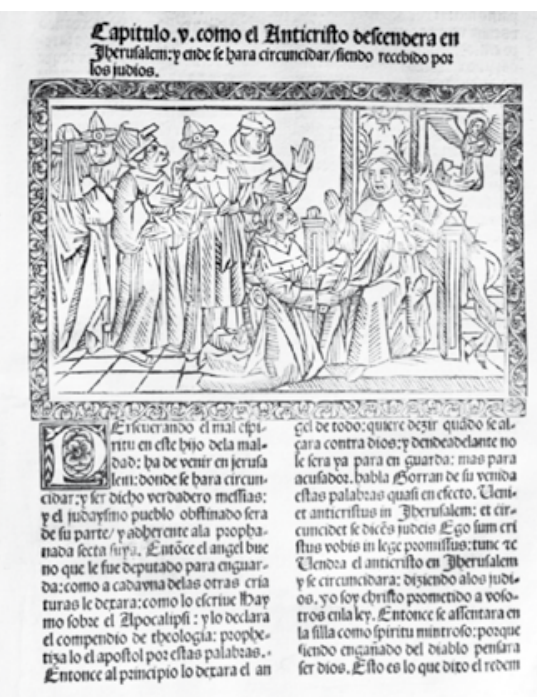

(6) La circuncisión del Anticristo. Nuevo grabado (Zaragoza: Pablo Hurus, 1496), Biblioteca Pública de Nueva York.

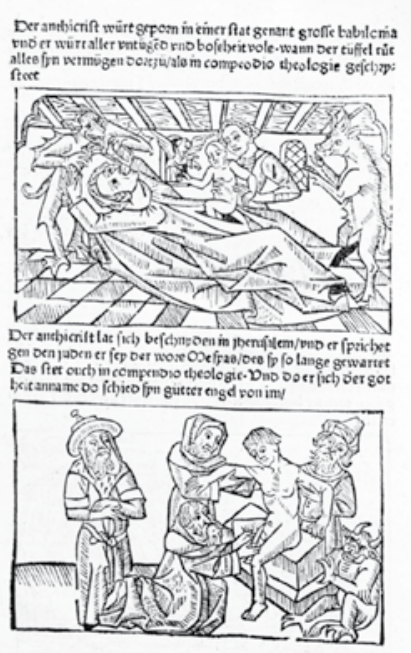

(7) La circuncisión del Anticristo. Der Antichrist [Estrasburgo: impresor del Anticristo, ca. 1482]. Munich, Biblioteca estatal de Baviera.

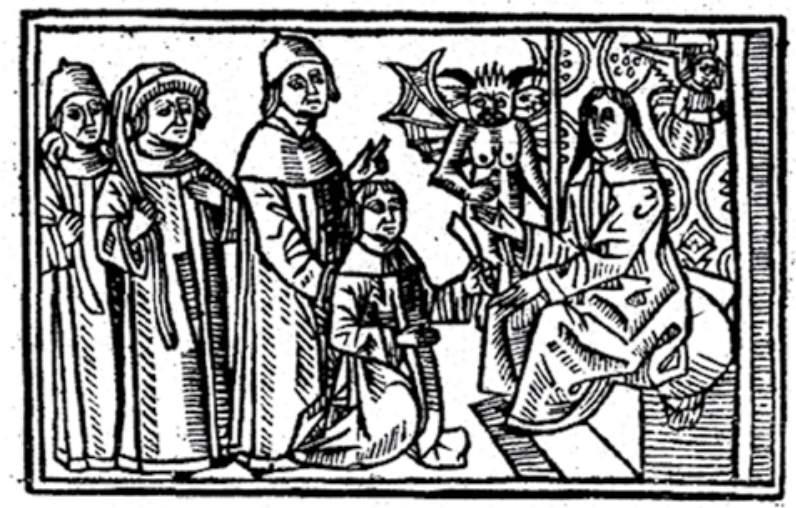

(8) La circuncisión del Anticristo (Burgos: Fadrique de Basilea, 1497). París, Biblioteca Nacional de Francia.

Otros están estrechamente relacionados con el contenido del capítulo y son tan específicos que tuvieron que abrirse expresamente para esta obra (imagen 9) ${ }^{19}$. Así sucede con la ilustración del triple milagro $\left(\mathrm{n}^{\mathrm{o}} 18\right)$ cuando el Anticristo:

${ }^{19}$ Para la distinción entre grabados referenciales y específicos, véase José Manuel Lucía Megías, «Leer el Cid en el siglo Xvi», en El Cid: de la materia épica a las crónicas caballerescas. Actas del Congreso Internacional IX Centenario de la muerte del Cid celebrado en la Universidad de Alcalá de Henares los días 19 y 20 de noviembre de 1999, ed. de Carlos Alvar, Fernando Gómez Redondo y Geor- 
Mandará salir [...] un cavallero armado de la cáscara de un huevo, y un venado de una peña, y colgará todo un castillo en una beta de hilo y lo hará estar en peso así en el aire [...] Estas obras tales no son maravillas que trahían consigo necessidad alguna ni ahun provecho, ahun a los cuerpos, puesto que dañassen para las almas (ff. 14v-15r).

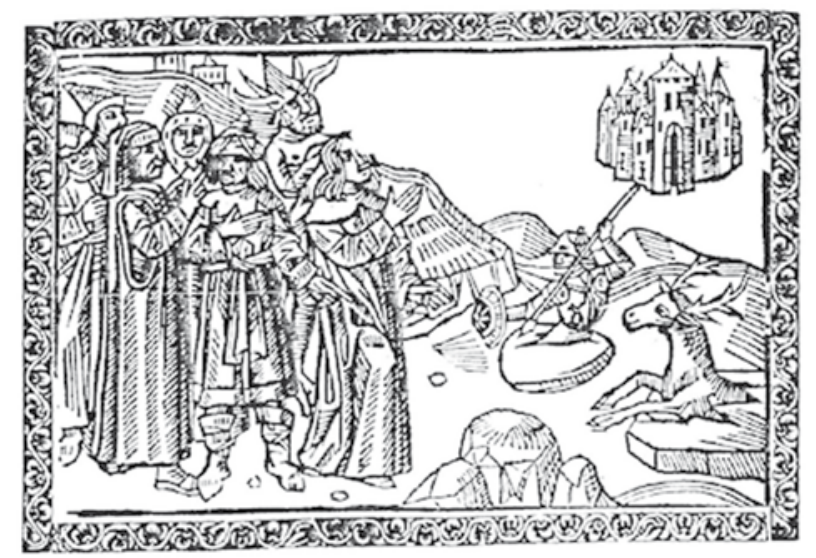

(9) Los tres milagros del Anticristo. Nuevo grabado (Zaragoza: Pablo Hurus, 1496). Biblioteca Pública de Nueva York.

Esta combinación de tres prodigios contra natura e «impropios», como los califica Martínez de Ampiés, no se incluía en la biografía de Adso de Montier y tampoco consta en los textos franceses ni italianos. Se ilustra en el manuscrito del Apocalipsis conservado en la Wellcome Library y en la tradición germánica, tanto en manuscritos como en libros xilográficos y tipográficos (imagen 10; imagen 11 ${ }^{20}$. No cabe, pues, pensar en ninguna reutilización de una imagen procedente de otra obra y solo podemos suponer que, al igual que los restantes tacos, fuera creado ex profeso para completar la edición, si, por razones desconocidas, no pudo hacerse Pablo Hurus con todas las maderas de la imprenta alemana, o bien, poco probable, se prepararon para otro incunable del que no tenemos noticia.

Pese a que era frecuente que los hermanos Hurus se sirvieran de grabados cortados en Alemania, la existencia de grabadores en Zaragoza está atestiguada tanto por la documentación encontrada como por la evidencia de algunas ediciones. Es posible que en algunos casos fueran artífices venidos de fuera, pero también existió un pequeño taller con artesanos locales, puesto que se conservan contratos para aprendices y para «maestros de tallar moldes

ges Martin, Alcalá, Universidad, 2002, pp. 407-421.

${ }^{20}$ Bernard McGinn, «Portraying Antichrist in the Middle Ages», art. cit., p. 20. 


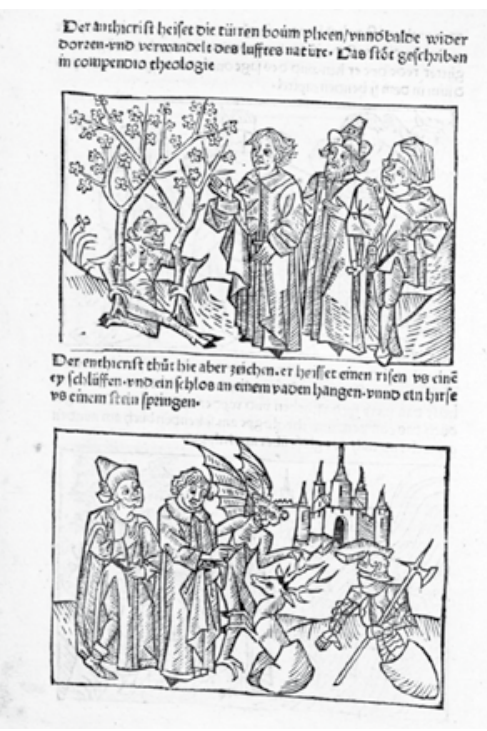

(10) Los tres milagros del Anticristo según el impreso alemán [Nürenberg, 1472]. Munich, Biblioteca estatal de Baviera.

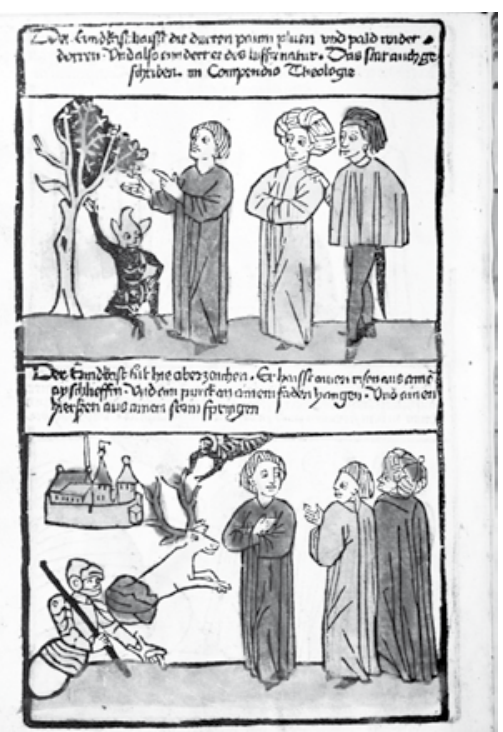

(11) Los tres milagros del Anticristo según un libro xilográfico alemán [Nürenberg, 1472]. Munich, Biblioteca estatal de Baviera.

de imágines». A ellos habría que atribuir, entre otros, los tacos de los escudos de Aragón o de los monarcas en las ediciones de los fueros y en las obras historiográficas, como la Crónica de España o la Crónica de Aragón de Vagad, pero también se encargarían de completar las series cuando se estropeaba alguna madera, como pudo ocurrir en la Historia del rey Apolonio, o era necesario ilustrar nuevas escenas, como sucede con las fábulas añadidas al Esopo. Mayor entidad tendría el autor del grabado de la Virgen del Pilar en el Triunfo de María del mismo Martín Martínez de Ampiés, el de la marca del impresor y, sobre todo, el creador de las magníficas ilustraciones de la Cárcel de amor, atribuidas al maestro Tomás Ubert ${ }^{21}$.

Como resultado de la intervención de distintos artistas se producen diversos cambios en el discurso visual que, para sintetizar, podemos concretar en dos: una acentuación del contenido antisemita y una diferente representación de la figura del Anticristo y de los diablos que le acompañan. El antisemitismo subyace en la biografía del Anticristo desde su nacimiento al considerarlo un descendiente de la tribu de Dan, lo que hará que entre sus seguidores

${ }^{21}$ Miguel Ángel Pallarés Jiménez, La imprenta de los incunables de Zaragoza y el comercio internacional del libro a finales del siglo xV, Zaragoza, Institución «Fernando el Católico», 2003, con amplia documentación; Manuel José Pedraza Gracia, «El grabado en Aragón en la Baja Edad Media», en La miniatura y el grabado de la Baja Edad Media en los archivos españoles, ed. de M. ${ }^{a}$ del Carmen Lacarra Ducay, Zaragoza, Institución «Fernando el Católico», 2012, pp. 75-101. 
predominen los de esta religión y él los premie reconstruyendo el templo de Jerusalén. Los grabados alemanes ya destacaban esta vinculación, pero en la nueva serie son más numerosos los tipos con los signos de identidad plástica del judío medieval. Suelen formar grupos con aspecto de estar conspirando y aparecen caracterizados por su nariz larga y ganchuda, barba puntiaguda y gorro o capirote cónico (véase la imagen 6). Las ilustraciones se corresponden con un texto en el que son frecuentes las apostillas contra ellos y su asociación con el Anticristo. Como recuerda Martínez de Ampiés desde los primeros folios, «el judaísmo, pueblo obstinado, será de su parte y adherente a la prophanada secta suya» (f. 6r), y el grabador ha sabido transmitir esta adhesión ${ }^{22}$.

El impulso para la figuración del Anticristo que partió de la obra de Adso de Montier implicaba dotarle de una forma humana, no monstruosa, como se expone con claridad en un manuscrito anónimo, redactado en catalán hacia 1449, y editado por Martin Aurell. Satán reúne su consejo y los distintos diablos le animan para que propicie ya la llegada del Anticristo a la tierra, aunque se discute cuál será la apariencia más adecuada para favorecer el engaño. La opinión de uno de los asistentes, antes del nacimiento del Anticristo, es determinante:

Al qual per lo sobiran Deu sera infusa anima ab cuberta humanal. Qui stuciosament per tu sera nodrit e ensenyat, qui enganara tota la universal generacio, car si tu't demostraves series conegut leugerament e no't creurien, per la gran terror que de tu hix e proceeix e gran spaventament terrible sobre potencies e forces de leo ${ }^{23}$.

Esa cubierta humana ordinaria lo hará irreconocible a los ojos de los demás y así logrará sus propósitos de forma más verosímil.

Los manuscritos e impresos se acogen a esta tendencia, pero, según sus creadores, la plasman de una forma u otra. La figuración más sorprendente se descubre en la tradición manuscrita alemana, donde el Anticristo siempre aparece con un nimbo en torno a la cabeza, que solo pierde en la última escena cuando es arrastrado al infierno. Los incunables franceses, y por ende los italianos que de ellos dependen, lo representan coronado, imagen que

${ }^{22}$ Andrew Gow, «Jewish Shock-Troops of the Apocalypse: Antichrist and the End, 1200-1600», en Journal of Millennial Studies, 1:1 (1998). [En línea]. Enlace: <http://www.mille.org/publications/summer98/summer98.html> [Consulta: 20/2/2016]; Paulino Rodríguez Barral, La imagen del judío en la España medieval. El conflicto entre cristianismo y judaísmo en las artes visuales góticas, Barcelona, Universitat Autònoma, 2008, pp. 235-247, trata sobre «Los judíos como seguidores del Anticristo».

${ }^{23}$ Martin Aurell, «La fin du monde, l'enfer et le roi: une prophétie catalane du $\mathrm{XV}^{\mathrm{e}}$ siècle (Bibliothèque de Carpentras, ms. 336, ff. 116v-156)», en Revue Mabillon, 5:66 (1994), pp. 143-177 (p. 15). 
tampoco es ajena a otros manuscritos, como el Apocalipsis de la biblioteca Wellcome, y refuerza su asociación con algunos tiranos ${ }^{24}$. Por el contrario, en los libros xilográficos y tipográficos de la imprenta alemana se opta por una imagen amable, de un hombre joven imberbe, con cabellos más bien cortos $\mathrm{y}$ vestido habitualmente con hábito, lo que le da un aire monacal (véase la imagen 10). Contrasta con la figura del Anticristo en la nueva serie de Hurus: más alto, que sobresale sobre el resto, rasgos más acentuados y duros, con cabellos largos a la altura de los hombros, pero imberbe, que parece contrafigura de Cristo, como recuerda el texto de Ampiés («Anti-cristo quiere dezir 'contra Cristo'», f. 15r). Para identificarlo siempre se complementa la escena con la presencia diabólica, cuyo aspecto también varía según el entallador (imagen 12).

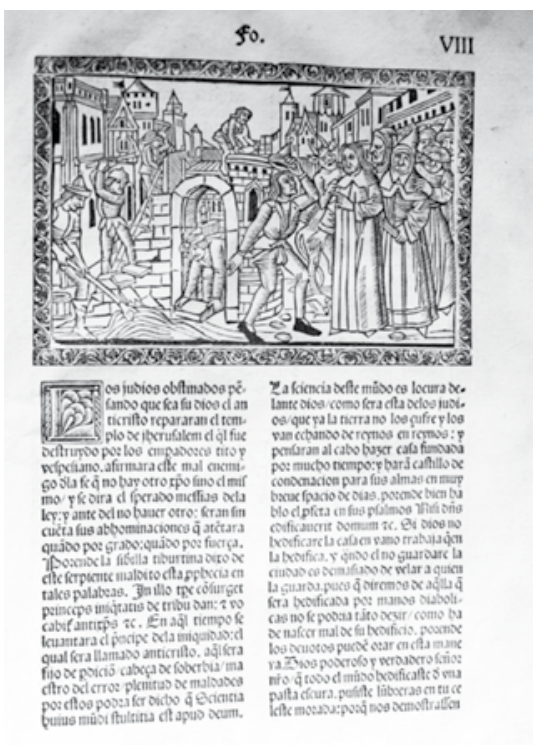

(12) El Anticristo con su diablo guardián dirige la reconstrucción del templo de Jerusalén. Nuevo grabado (Zaragoza: Pablo Hurus, 1496). Biblioteca Pública de Nueva York.

Tanto en los grabados alemanes como en la nueva serie incorporada por Hurus se añaden figuras diabólicas para reconocer la verdadera naturaleza del personaje representado. En uno y otro caso la imaginería diabólica parece responder a una tipología híbrida, próxima al sátiro antiguo: provisto de patas con pezuñas, orejas velludas, rabo, lengua afilada, uno o dos cuernos, etc., y siempre desnudos o cubiertos de pelo. Se encuentran a medio camino entre el mundo animal y el humano ${ }^{25}$. En los grabados del Antichrist se presentan normalmente varios en cada escena, con formas muy diversas, que parecen reflejar su capacidad de transformación. $\mathrm{Su}$ proximidad al mundo animal hace que adopten a veces apariencia de serpiente, rostro

\footnotetext{
${ }^{24}$ Pese a que los grabados interiores de los incunables franceses muestran al Anticristo coronado, en la portada se le representa como la bestia del Apocalipsis, con cuerpo de felino o león y seis cabezas de hidra coronadas.

${ }^{25}$ Puede consultarse el clásico trabajo de Joaquín Yarza Luaces, «Del ángel caído al diablo medieval», en Boletín del Seminario de Estudios de Arte y Arqueología: BSAA, 45 (1979), pp. 299-316, aunque en ningún caso se hace mención a esta tradición impresa.
} 
de cerdo o utilicen alas de murciélago, o incluso cuenten con una cabeza suplementaria en el vientre. En la imagen 2, de los diablos que asisten al parto del Anticristo, uno tiene cabeza de cerdo y el otro parece un murciélago. No suelen ir pegados al Anticristo sino que asoman en posturas extrañas, a veces parecen ser pisoteados, lo que avala la impresión de que no son visibles para el resto. Su rostro es muy expresivo y sus muecas les confieren un carácter burlón y casi cómico. Por el contrario, en la nueva serie de grabados incorporados por Pablo Hurus solo aparece un diablo por escena, siempre detrás de la figura del Anticristo, a quien en ocasiones parece guiar. Pese a contar también con los característicos rasgos de sátiro, su rostro es más humano, incluso provisto de barba, como en la imagen 9. Su posición lo convierte en un auténtico diablo guardián, tras la marcha del ángel de la guarda. En ningún caso esta iconografía diabólica corresponde con los monstruos de los Beatos ni del Apocalipsis, pero su representación resulta más cómica y próxima a la demonología popular en los grabados alemanes y mucho más grave y aterradora en la nueva serie de Hurus.

El estudio de los grabados de nuestros impresos es una asignatura pendiente, que solo en fechas recientes comienza a abordarse, siendo muy necesaria una labor sistemática de descripción, identificación y catalogación. Las nuevas tecnologías, con las posibilidades que abren para facilitar la visualización de los mismos, pueden ser unas herramientas imprescindibles. El caso del Libro del Anticristo no es una excepción. En las fichas catalográficas de la princeps no se indica el número de grabados, su ubicación, medidas, ni la procedencia de los mismos, dando por supuesto a lo sumo su origen germánico. Como hemos podido comprobar la afirmación no es totalmente cierta. Pese a que gran parte de las escenas se ilustran con las mismas maderas creadas en la imprenta de Estrasburgo, hay ocho tacos de distinta factura y que, descartados otros posibles modelos, deben considerarse entallados en la oficina de Pablo Hurus. Esta diferencia no ha sido percibida hasta ahora por los estudiosos, posiblemente por partir del incunable burgalés, mucho más accesible, pero en el que, al estar todos los grabados copiados por la misma mano, se atenúan considerablemente las diferencias.

La diversa procedencia de las imágenes por un lado y la adaptación de la obra a un nuevo contexto proporcionan una diferente lectura. Los impresos alemanes, con los que guarda directa dependencia el incunable zaragozano, eran un producto popular, que permitía incluso a los iletrados seguir la historia del Anticristo a partir de un libro de imágenes, acompañado de breves textos didácticos. La correlación entre el documento escrito y el visual se modifica totalmente en el impreso español al usarse como complemento del texto 
erudito preparado de Martín Martínez de Ampiés. Por otra parte, las nuevas imágenes dotan de mayor gravedad al conjunto, tanto por su creciente antisemitismo como por la presencia severa del Anticristo y su diablo guardián. En resumen, el Libro del Anticristo, impreso por Pablo Hurus en 1496, inaugura en la Península una lectura iconográfica de la biografía de este personaje que impresionaría vivamente a quienes tuvieran el libro entre sus manos.

Recibido: 29/03/2016

Aceptado: 10/06/2016 
RESUMEN: En el artículo se estudian las imágenes que ilustran el Libro del Anticristo en la edición princeps (Zaragoza: Pablo Hurus, 1496). Una gran parte de los grabados proceden de la imprenta alemana, donde habían sido utilizados en los tres Antichrist impresos en Estrasburgo hacia 1482, acompañados de unos breves textos. La correlación entre el documento escrito y el visual se modifica totalmente en el impreso español al usarse como complemento del texto erudito preparado de Martín Martínez de Ampiés. Se llama la atención sobre ocho tacos de distinta factura, posiblemente entallados en la oficina de Pablo Hurus. Estas nuevas imágenes dotan de mayor gravedad al conjunto, tanto por su creciente antisemitismo como por la presencia severa del Anticristo y su diablo guardián.

PALABRAS ClaVE: Anticristo. Grabados. Incunables. Imprenta alemana.

\section{The Series of WoOdCUtS IN THE Libro DEL ANTICRISTO \\ [Zaragoza: Pablo Hurus, 1496]}

AbSTRACT: This paper aims to study the ensemble of xylographies that illustrates the Libro del Anticristo princeps edition [Zaragoza: Pablo Hurus, 1496]. A significant part of the woodcuts comes from German printing houses, where they had been used in three Antichrists, accompanied with a brief piece of text and already printed in Strasbourg around 1482. The interrelationship between written text and visual component is entirely modified in the Spanish printing, as they have been used as an accompaniment for the scholar text arranged by Martín Martínez de Ampiés. The attention is drawn to eight xylographies from different executions and probably whittled in Pablo Hurus' studio. These new images give more seriousness to the ensemble, as for them showing a growing anti-Semitism and for the strict presence of Antichrist and his devil custodian.

KEYwORDS: Antichrist. Woodcuts. Incunabula. German Printing. 